\title{
CORRESPONDENCE
}

\section{Mr Arthur Frank}

SiR, - The implications in Judy Redfearn's article (29 May) must not be allowed to pass unchallenged. I cannot speak for other directors but I trust that you will correct some of the misconceptions in the piece insofar as they may be thought to apply to Mr Frank's relations with the National Army Museum.

Three years ago he presented 80 optical and other instruments used by the British Army. They came free of any charges or conditions. This year the museum again benefited from Mr Frank's generosity when we received another 33 instruments. The second series came with the painless condition that they are on loan until such time as they can be put on display. They will then become the inalienable property of the museum, an invaluable addition to a section of the museum's collections which was extremely weak.

The caption "Arthur Frank with his instruments: gift horse or salesman?" is as unjust as it is clumsy. It is misleading, offensive and unworthy of a journal of the standing rightly enjoyed by Nature. Yours faithfully

William Reid

National Army Museum,

London $S W 3, U K$

\section{Book prices again}

SIR, - Dr Brindley (12 June) points out that paperbacks are published, on the average, at less than half the selling price of the cloth edition of the same title. He suggests that publishers of scientific books should make paperbacks more widely available to increase sales and perhaps profits.

The actual difference in cost between producing a paperback and cloth edition is about $65 \mathrm{p}$ for a book of 300 pages. What most publishers do is to subsidise the paperback edition by overpricing the cloth edition; this also happens in the pricing of journals where libraries have to pay an inflated rate which subsidises the cost of supplying copies to members. It should be understood, therefore, that where there is a dual edition the paperback is made available to individuals at an artificially low price at the expense of libraries. There is a strong feeling among publishers that this is just as most libraries are still allowing widespread photocopying which must reduce sales Yours faithfully,

ROBERT CAMPBELI Blackwell Scientific Publications Ltd., Oxford, UK

SIR, - The comparison of typical paperback and hardback book prices tabulated by $\mathrm{G} \mathrm{W}$ Brindley ( 12 June) is illuminating, but I could hardly disagree more strongly with the conclusion which he draws from these data. The fact that paperback editions are usually much cheaper does not necessarily imply that it would be in the public interest for them to be made yet more widely available. It would surely be infinitely preferable to persuade publishers to adopt a pricing policy which honestly reflected the difference in unit costs ( $c a £ 1-£ 3$ ) of the two types of binding.

An alternative way of looking at G W Brindley's figures is to work out, in each case, the publisher's pretended costs incurred in providing hard covers as opposed to paper: the booby prize clearly falls to Elsevier, who seek to extort from the unfortunate purchaser an astounding $\$ 45.75$, merely for putting covers on their Practical methods in electron microscopy, followed by U California Press who price the covers of Mezozoic mammals at an almost equally surprising $£ 15.25$. It is admittedly unfair to make this sort of comparison without taking proper account of the comparative length, page size, quality and so on of the books in question; but this hardly aiters the central conclusion, which is that the alleged cost of hard covers bears remarkably little relation to reality

The explanation, one is told, lies in the publishers' naive belief that libraries will always purchase hardback editions, virtually regardless of cost, so that profits can supposedly be maximised by raising the hardback prices to increasingly absurd levels. The ordinary reader is then offered an edition identical in every respect except that it is bound between paper covers and carries a rather more realistic price tag. The fact that he or she would often prefer to pay an extra pound or so in order to gain the durability and convenience provided by a hard cover, is conveniently ignored.

There appears to be little justification for this abominable practice, which is a continuing source of despair for bibliophiles and of frustration for practising scientists. It is surely high time that it was brought to an end. Is there really no hope of persuading publishers to move back towards a pricing policy showing some degree of sensitivity towards the interests of ordinary book buyers?

$$
\text { Yours faithfully }
$$

Physics Department

University of Lancaster, $U K$

\section{Parkinson extended}

SIR, - In his letter "Expanding on Parkinson's law" R. Moss produces the relations $I_{\mathrm{ai}}=W^{2} / A+A$ where $I_{\mathrm{ai}}$ is the workload of a single administrator, $W$ is the number of productive workers and $A$ the number of administrators, for the most advanced state of any organisation. He then suggests that this relationship will lead to a limiting ratio of one administrator for each productive worker. Under some conditions, however, the relationship gives rise to a bureaucracy which expands without limit.

The workload of a single administrator, $l_{\text {ai }}$ falls to $2 W$ as $A \rightarrow W$ and increases thereafter. If the objective of the chief administrator is to minimise $l_{a}$ the number of administrators will tend to $W$, but this will not be the case if instead the chief administrator seeks to increase the number of administrators until some aspiration level $O$ is reached. If $O$ is greater than $2 W$, recruitment will slow down before the Moss ratio is reached. If, on the other hand, $O$ is less than $2 W$, the individual workload of an administrator will never reach the aspiration level, no matter how many administrators are employed, and recruitment will proceed at an ever more furious pace as more administrators are needed to meet the demands of an ever-increasing workload. Even if the chief administrator does attempt to minimise individual workloads, should the number of administrators ever exceed the number of productive workers the chief administrator will find himself appointing still more administrators in an attempt to regain his previous workloads.

The Moss ratio can thus be envisaged not as a limit on the number of administrators but as an event horizon beyond which a bureaucracy is doomed to expand ever more rapidly in an attempt to cope with the ever-increasing flow of minutes and memoranda generated within its own hounds. Ultimately it is unable to cope even witll that function and becomes a veritable black hole of forms and minutes. Yours faithfully

J.C. THORPE

Physics Department

Manchester Polytechnic,

Manchester, UK.

\section{Ethnographic DNA}

SiR - Several of the articles in your issue of 26 June note that both confusion and entertainment can be had by considering DNA as selfish, ignorant or, indeed, both. Perhaps these terms are not so much anthromorphic as ethological. Competing DNA molecules are, after all, made up of four main nucleotides, the deoxyribonucleotides of that famous intratribal totem sub-group A, T,C and G. We know from previous analysis of intra-tribal totem preferences that totem clan $A$ is matched by totem clan $\mathrm{T}$, and so is totem clan $\mathrm{G}$ with $\mathrm{C}$. Commonly called base-pairing, it is of course fully understood that neither a moral imputation is implied by base, nor sexual by pairing.

We have yet to learn what resources competing DNA molecules had thermodynamically to writhe over, but it may very well be that the totems of $A, T, C$ and $G$ hold secrets. For example, codons with their middle base $T$ preferentially code amino acids with polar side chains, while those with $\mathrm{A}$ as centre base in the triplet preferentially code non-polar side-chain amino acids. There appears litle bias towards polar or non-polar by codons with $\mathrm{C}$ or $\mathrm{G}$ as the triplet centre ${ }^{1}$. Closer inspection reveals that $A$ is replete with two amino groups and $\mathrm{T}$ with two hydroxy groups on the base nucleus; $G$ has an amino and a hydroxy, so does C. As Kipling noted, there are 99 ways of making tribal lays - but in this tribe why should a totem of $-\mathrm{NH}_{2}$ mean non polar coding, and - $\mathrm{OH}$ polar? What happens to totem loyalties when $-\mathrm{NH}_{2}$ and -OH are paired, in $\mathrm{C}$ and $\mathrm{G}$ ? The strong totem preference is annulled - are we seeing cultural impoverishment by mere group composition?

Since it appears that we have no answers to these questions at the anthropomorphic, ethological or any other level, it may be salutary to recall that molecular biology is about molecules - not selfish this or that. If this trend continues we can expect to see defrocked DNA and rampant tRNA. Yours faithfully

34 Avenue Gardens, ANTHONY HARRIS

\section{London $W$}

1. Wolfenden, R.V; Cullis, P.M. \& Southgate, C.C.F. Science, 206, 575 (1979).

\section{Conversion courses}

SIR - My attention has been drawn to the reference in Robert Walgate's article on Dr Shallis ( 7 February) to our conversion course from arts to sciences and to the fact that it has closed. Sadly this is true; it closed seven years ago for lack of applicants. Not all our students were as successful as Mike Shallis, but a number are now active as scientists. We demonstrated that with motivated students it was possible and not too difficult to effect such a conversion, and we gained experience in the ways of doing it and the pitfalls to avoid. Although the course has closed, the experience is still there and available to anyone who wishes to start such a course again. There is surely need for it as long as our schools force children into choices at an age too early for them to know their minds. Yours faithfully

University of Surrey,

L R B ELTON 